\title{
TOGETHER WE CAN MAKE IT: EXPLORING WHY CONSUMERS ENGAGE IN BOYCOTTS
}

\author{
Carmen-Maria Albrecht, University of Mannheim, Germany \\ Daniel Heinrich, University of Mannheim, Germany \\ Mathew Joseph, St. Mary's University, USA
}

\begin{abstract}
Nowadays companies are more and more judged by consumers whether they act in a socially responsible way. But more and more often, consumers do not only judge the behavioral acts of the company, but also overtly express their discontent with the company. In other words, companies risk being the target of boycotts, in that consumers refuse to buy their brands if they act unethically. Based on a literature review and several in-depth-interviews, the current study identifies antecedents to consumers' boycott participation. A second empirical study reveals key drivers of consumers' boycott participation intention. While some of them are useful for boycott organizers to arrange boycotts successfully, others are manageable factors for companies to prevent consumers from participating in boycotts.
\end{abstract}

References available upon request 